\title{
KRONIK
}

\section{Seniortænketankens forståelse af seniorernes arbejdsliv - en kritik}

\author{
Niels Møller, Lisbet Theilgaard \& Mads Christoffersen
}

\section{Baggrund}

Befolkningen bliver ældre. Folk lever længere, mange har et godt heldbred og god økonomi. Der er brug for seniorerne i arbejdslivet. Mange politiske aktører arbejder derfor på, at befolkningen skal blive i arbejde i længere tid, hvis de ikke er nedslidte. En af de vigtige aktører i denne sammenhæng er Seniortoenketanken, som blev nedsat af den tidligere regering.

Seniortaenketanken har nu arbejdet et par år med at finde frem til anbefalinger og initiativer, der kan fastholde seniorer i arbejdet. Som foreløbig afslutning på sit arbejde har Seniortoenketanken produceret en rapport, som vi vil undersøge kritisk i denne kronik. Vi lægger vægt på to perspektiver: Det ene er, at Tænketankens forståelse af arbejdsmiljø er snæver og hovedsagelig ser bort fra de positive faktorer i arbejdsmiljøet. Det andet er, at Tænketanken ser seniorer i arbejde ud fra et skåneperspektiv: Belastningerne skal reduceres og måske skal arbejdstiden nedsættes for at få seniorer til at arbejde længere.

Vi synes selvfølgelig, det er fornuftigt at skåne nedslidte seniorer. Vores pointe er, at der er mange ressourcestærke seniorer, som ønsker udfordringer, mening og indflydelse. Det er det, der motiverer dem til at arbejde.

\section{Arbejdet forstået baglæns}

Baggrunden for vores undersøgelse af tænketankens rapport er et projekt, vi gennemførte i 2017-2019. Vi kaldte projektet Fortidsvoerksteder. Projektet mundede ud i en bog Arbejdet forstået bagloens, som udkom i 2019 på forlaget Frydenlund.

Ideen om fortidsværksteder er inspireret af fremtidsværksteder og historieværksteder. I fortidsværkstedet fortæller seniorpensionister historier om deres afsluttede arbejdsliv.

Tolv faggrupper deltog i de 12 fortidsværksteder, der blev afholdt fra januar til november 2017: sociologer, ingeniører, læger, IT-folk, bibliotekarer, journalister, politifolk, teknikere, bankansatte, sosu'er, 3F'ere og folk fra byggefagene

Det enkelte fortidsværksted varede én dag med ca. 10-12 deltagere. Hver enkelt deltager fortalte om eget arbejdsliv på godt og ondt, erfaringer og refleksioner derfra og om hans eller hendes overgang til seniorlivet og sit aktuelle liv. Undervejs opstod diskussioner og fælles refleksioner over historierne.

Vi rekrutterede deltagerne gennem en bred invitation til seniorklubber, fagforeninger og netværk. Deltagerne meldte selv tilbage, hvis de var interesserede i at deltage. Vi udvalgte herefter ud fra "først til mølle" princippet. Udvælgelsen betyder formodentlig, at deltagerne har været aktive i deres arbejdsliv 
og fortsat er det i deres seniorliv. De er ikke repræsentative for deres faggruppe. Historierne og diskussionerne i værkstederne viste, at deltagerne var ressourcestærke mennesker. Udvælgelsesmetoden betyder videre, at vores fortolkning i bogen og i denne kronik af, hvad der er generelt for de 12 faggrupper, gælder de ressourcestærkes og aktives erfaringer og refleksioner over arbejdslivet og seniorpensionistlivet.

Bogen indeholder ekstraktet af historier, konkrete erfaringer, refleksioner og råd fra deltagerne. Den giver et bredt billede af arbejdslivet gennem de sidste 40-50 år i Danmark. Der fortælles om erfaringer med ledere, ny teknologi, konflikter, samarbejde, fyringer og så videre.

Mening i arbejdet, samarbejde og sociale relationer er det mest positive deltagerne fortalte om deres arbejdsliv. Langt de fleste havde været glade for deres arbejdsliv, og de lagde vægt på, at de havde haft en aktiv rolle i arbejdet og i virksomheden. Det var disse positive faktorer, der havde motiveret deltagerne til at arbejde livet igennem, og som var vigtige for dem som seniorer. Samlet set er disse positive faktorer med til at skabe et udviklende psykosocialt arbejdsmiljø. Det er disse resultater af fortidsværkstederne, vi ser som faktorer, der motiverer ressourcestærke seniorer til at arbejde i længere tid.

Det værste deltagerne havde oplevet var dårlig ledelse og kontrollerende ledelsessystemer. Det var den negative faktor i det psykiske arbejdsmiljø, der oftest blev nævnt. Der blev også fortalt om god ledelse, men ikke så ofte som om dårlig ledelse. Når den findes, er god ledelse formentligt en fastholdelsesfaktor.

\section{Seniortænketanken om seniorernes arbejdsmiljø}

Tænketanken skriver meget om arbejdsmiljøets betydning gennem hele livet for helbred og arbejdsevne. På den lange bane ses arbejds- miljøet som en forudsætning for, at medarbejderne kan arbejde længere. Tænketanken håber og forudsætter, at den eksisterende og forbedrede arbejdsmiljøregulering vil sikre dette fremover.

Tænketanken fokuserer herefter i kapitel 1 på det, vi ser som en beskyttelsestankegang i forhold til seniorerne. Den eneste anbefaling, som decideret nævner arbejdsmiljø med titlen "Der gennemføres pilotforsøg om arbejdsmiljøvejledning" er målrettet særligt udsatte brancher. Det handler om at reducere belastningerne eller reducere arbejdstiden for seniorerne. Fokus på de udsatte og nedslidte er det centrale for tænketanken. Det er helt relevant. Desværre sker der en nedtoning af de positive faktorer i arbejdsmiljøet, der kan motivere og fastholde de ressourcestærke seniorer.

Forskellige steder i rapporten anerkendes det, at seniorerne har både ressourcer og særligt værdifulde kompetencer. Men anbefalingerne på dette område er vage og uforpligtende: Virksomhederne skal tænke i nye måder for at fastholde seniorerne og lederne skal tale med seniorerne om det.

Vores erfaringer er, at når det drejer sig om de ressourcestærke seniorer, er et udviklende arbejde med mening det, der motiverer til at blive i arbejdet, selv om det ikke længere er en økonomisk nødvendighed. Et udviklende psykosocialt arbejdsmiljø er formentlig den vigtigste fastholdelsesfaktor for ressourcestærke seniorer. Dette perspektiv savner vi i rapporten.

Mange af tænketankens beskrivelser af seniorernes arbejdsliv og forslag til fastholdelse er som skrevet præget af en skånetilgang. Skånetanken er rimelig, da mange seniorer har et dårligt helbred og reduceret arbejdsevne. Der er seniorer, som gennem livet har haft et hårdt arbejdsmiljø, eller som på grund af dårligt helbred har svært ved at klare arbejdets krav. Hvis de skal fastholdes, skal de hjælpes med forskellige tiltag, som 
for eksempel nedsat arbejdstid eller lettere arbejde.

Det er ganske fornuftige tiltag, når arbejdsmiljøproblemerne er kvantitative og tidsafhængige. Men hvis en senior fx er udsat for et dårligt psykosocialt arbejdsmiljø i form af fx dårlig ledelse eller mobning, hjælper det sjældent med kortere arbejdstid.

Det er ikke kun arbejdsmiljøet, der har betydning for, om seniorerne arbejder i længere tid. Tænketanken har en lang række forslag til en anden type foranstaltninger, som virksomhederne kan iværksætte, der skal fastholde seniorerne i arbejde. De handler hovedsageligt om kommunikation. Lederne opfordres til at tage samtaler med seniorerne i god tid og tilrettelægge arbejdet for seniorerne ud fra deres behov.

Tænketanken foreslår også, at pensionsordningerne skal gøres mere gennemskuelige, så seniorer kan se de økonomiske fordele ved at arbejde længere, samt at der anvendes økonomiske incitamenter til at fastholde seniorer i arbejde. Tænketanken peger på, at $ø$ konomi betyder mest for lønmodtagere med lave uddannelser.

Rapporten peger således på en række faktorer og initiativer, der kan fastholde seniorer i arbejde. Vi mener, at disse faktorer og initiativer er vigtige, men de repræsenterer ydre former for motivation (extrinsic) for at blive i arbejde. Resultaterne af fortidsværkstederne peger på, at et meningsfyldt arbejde med udfordringer udgør den vigtigste indre motivation (intrinsic) for ressourcestærke medarbejdere. Både i det daglige arbejde og $\mathrm{i}$ beslutningen om at fortsætte med at arbejde efter pensionsalderen.

\section{Seniortænketanken ser trods alt seniorerne som en ressource}

I rapportens kapitel 1 og 2 fremgår det forskellige steder, at tænketanken ser seniorerne som en ressource for virksomhederne. Seniorerne er aktive, har værdifulde erfaringer og kan være positive rollemodeller for yngre kolleger.

Tænketanken anbefaler, at lederne skal anerkende seniorernes værdi og gå i dialog med dem. En konkret anbefaling er, at seniorerne og deres virksomhed skal sikre en dokumentation af de kompetencer, seniorerne har erhvervet gennem et langt arbejdsliv (realkompetencer).

Selvom Seniortænketanken primært anlægger et skåneperspektiv, er det positivt, at tænketanken også anlægger et ressourceperspektiv på seniorerne. Tænketanken kunne godt have forfulgt dette positive perspektiv på seniorerne mere gennemgående.

\section{Seniorerne er en ressource og bliver i arbejdet, hvis arbejdet er godt og udfordrende}

Seniortænketanken har selv skabt viden, som understøtter dette perspektiv. I kapitel 4 om anbefalingernes videns grundlag fremføres der mange gode argumenter for at se seniorerne, som en ressource, som ønsker indflydelse:

"For funktionoerer ses der en positiv sammenhoeng mellem at forvente at troekke sig senere tilbage og at have indflydelse på sin arbejdssituation, at kunne organisere sit eget arbejde samt at kunne bruge sine kvalifikationer rigtigt."

Tilsvarende skriver tænketanken, at medarbejdere der oplever, at der er brug for deres ressourcer i arbejdet og at de bidrager til at skabe værdi for andre, motiveres til at blive længere tid $\mathrm{i}$ arbejdet.

Det passer fint til resultaterne af fortidsværkstederne. Deltagerne ønskede mening, udfordringer, indflydelse og udvikling. De talte ikke om, at de skulle skånes som seniorer. De lagde derimod vægt på, at de leverede værdi på grund af deres kompetencer, og at de gjorde det sammen med kolleger. Det skaber mening og arbejdsglæde. Det er måske den mest grundlæggende motivation for at arbejde. 
Den fastholdelses- og motivationsfaktor har tænketankens 'politikere' desværre kun lidt øje for. Vi antager, at Seniortænketankens udvalgsmedlemmer har haft mest fokus på rapportens tre første kapitler og rapportens anbefalinger. Her overses de positive motivationsfaktorer for at blive i arbejde.

Der er efter vores mening megen vigtig viden i kapitel 4 i rapporten om, hvad der i arbejdslivet motiverer ressourcestærke seniorer til at blive ved at arbejde. Desværre har denne viden ikke givet grundlag for de centrale kapitler i rapporten og dens anbefalinger om seniorernes arbejdsmiljø, som i høj grad baserer sig på et skåneperspektiv.

\section{Et meningsfyldt arbejde motiverer}

De ressourcestærke seniorer vil arbejde ud over pensionsalderen, hvis de har et attraktivt og godt arbejde. De vil arbejde, fordi de har lyst til det og i mindre omfang, fordi det er en økonomisk nødvendighed. De vil arbejde længere, hvis deres arbejde giver dem mulighed for at bruge sig selv sammen med andre. Det skaber identitet og mening. Kapitel 4 i rapporten formulerer dette klart:

"Alt $i$ alt peger seniorer, som bliver på arbejdsmarkedet efter pensionsalderen, blandt andet $p \stackrel{\circ}{\text {, }}$ at faglig stolthed og en folelse af at voere kompetent og efterspurgt er afgørende for beslutningen om at fortsaette med at arbejde. Samtidig noevner seniormedarbejderne, at det kollegiale foellesskab og et godt samspil med ledelsen er vigtigt for arbejdsgloeden."

Dette svarer helt til resultaterne af vores fortidsværksteder. Samspillet mellem på den ene side personlige kompetencer og identitet og på den anden side arbejdets indhold og udformning er helt afgørende. Hvis disse to faktorer ikke spiller sammen, kan det være en vigtig motivation for at forlade arbejdet. Det at skabe det gode og produktive samspil er klart en ledelsesopgave, som vi om lidt skal komme ind på.

Hvis ressourcestærke seniorer ikke oplever et godt samspil, står de - i modsætning til andre lønmodtagere - $\mathrm{i}$ den heldige situation, at de kan sige nej tak og gå på pension.

\section{Fastholdelse af ressourcestærke seniorer og et godt og meningsfyldt arbejde}

Vi er meget enige i tænketankens påpegning af, at arbejdets indhold er en vigtig fastholdelsesfaktor; måske ikke for alle faggrupper, men for de fleste. Vi synes imidlertid, at denne erkendelse optræder for sporadisk i tænketankes rapport og er usynlig i anbefalingerne.

Vi er også enige i, at seniorerne er en vigtig ressource, som virksomheder og samfund bør satse på at fastholde. Men tænketanken beskæftiger sig kun begrænset med, hvad der får ressourcestærke seniorer til at blive længere tid i arbejde, og hvad der får dem til at forlade arbejdet. Der skal helt andre fastholdelses- og motivationsfaktorer til for yderligere at fastholde de ressourcestærke seniorer. Faktorer som tænketanken ikke beskæftiger sig med.

Vi vil her kaste mere lys over, hvad der får ressourcestærke seniorer til at blive i arbejdet og hvad der får dem til at forlade det. Det vil vi gøre ved at fortælle, hvad seniorerne i vores fortidsværksteder fortalte om gode og motiverende faktorer i deres forgangne arbejdsliv. Det skal her huskes, som vi tidligere skrev, at udvælgelsen af deltagerne gør, at resultaterne af fortidsværkstederne ikke er repræsentative for hele grupper af seniorer.

\section{Seniorer vil bruge deres kompetencer}

Mange af seniorerne i vores fortidsværksteder fortalte, at de gerne ville have arbejdet 
længere end til den normale pensionsalder. Nogle fortalte ovenikøbet, at de havde dårlig samvittighed over, at deres kunnen og kompetencer ikke blev brugt. En stor del af deltagerne havde mange småjobs som seniorpensionister.

\section{Seniorerne har haft et godt arbejdsliv}

Når vi ser på beretningerne på tværs af gruppernes historier, så tegner der sig nogle klare fællestræk. Generelt har deltagerne været tilfredse med deres arbejdsliv, og de formulerede flere positive vurderinger om deres arbejdsliv end negative. For næsten alle deltagere har arbejdslivet haft uhyre stor betydning, og det har givet meget mening at skabe værdi for andre og sammen med andre.

Gode kolleger på arbejdspladserne har haft enorm betydning for vores deltagere. Det samme gælder for mulighederne for at udvikle sig fagligt og have den størst mulige kontrol over sine arbejdsvilkår. Dette er nogle af forudsætningerne for, at deltagerne oplevede, at deres arbejde var meningsfyldt.

\section{Dårlig ledelse er det værste}

Deltagerne gjorde det meget klart, at de havde oplevet både god og dårlig ledelse. God ledelse var efterspurgt, men relativt sjælden. Dårlig ledelse var klart dominerende i mange beretninger. Faktisk var dårlig ledelse det hyppigst nævnte, når man spurgte til arbejdets negative sider.

Der var ret stor forskel på de forskellige faggruppers reaktion på dårlig ledelse. Nogle kunne i kraft af deres faglighed som ingeniører, sociologer og læger værne sig imod dårlig ledelse, bygningsarbejderne brugte den kollektive solidaritet som skjold, mens andre havde været mere udsatte for skiftende ledere, vilkårlige beslutninger og ustandselige organisationsændringer. Dette gjaldt især for sosu'er, bankfolk og i nogen udstrækning IT-folk. Ganske mange fra disse faggrupper valgte at forlade arbejdsmarkedet, fordi de fandt, at dårlige ledere skabte uacceptable vilkår.

Der er tydelige tegn på, at mange deltagere gennem deres arbejdsliv har erfaret, at det blev stadigt mere vanskeligt at fastholde den mening med arbejdet, som de oplevede i 80'erne og 90'erne. Arbejdets mening og medarbejdernes autonomi blev i den senere periode indskrænket, produkternes kvalitet forringet og de sociale relationer blandt kollegerne blev ødelagt af nye ledelseskoncepter, som prioriterede indtjening, effektivitet og kontrol.

\section{Styrker og svagheder ved Seniortænketankens rapport}

Det er tænketankens fortjeneste, at den skaber fokus på et sundt arbejdsmiljø, som forudsætning for at seniorerne vil blive længere i arbejde. Det gælder på den helt lange bane, hvor et sundt arbejdsmiljø gennem hele livet fastholder kapaciteten til at arbejde som senior i mange år. Det gælder på den korte bane, hvor et hensynsfuldt arbejdsmiljø muliggør, at seniorerne med forringet arbejdsevne og helbred kan arbejde i flere år.

Tænketanken har dog ikke meget fokus på de faktorer, der kan fastholde ressourcestærke seniorer i arbejdet. Vores erfaringer peger på, at en vigtig fastholdelsesfaktor er mulighederne for, at seniorer oplever mening $i$ arbejdet og kan anvende og udvikle deres kompetencer og arbejdsevne. God ledelse og organisering af arbejdet kan skabe mulighederne for et udviklende og meningsfyldt arbejde. Et arbejde der giver indflydelse og udfordringer. Det skaber lyst til at arbejde.

Vores resultater peger på, at dårlige ledere og kontrollerende ledelsessystemer er det værste, deltagerne i fortidsværksteder har oplevet i deres arbejdsliv. Det kunne tyde 
på, at dårlig ledelse har været og er en meget væsentlig frastødningsfaktor. Lederne har således en væsentlig opgave i at organisere arbejdet, så det er motiverende især for de ressourcestærke seniorer. Arbejdet kan motivere til at blive, hvis det giver indflydelse og udfordringer. Tænketanken har ikke fokus på dårlig ledelse som frastødning eller ledernes potentielle mulighed for at fastholde seniorerne via arbejdets organisering.
Som motivation for sit arbejde skriver Seniortænketanken, at seniorerne skal fastholdes længere tid i arbejde for at sikre samfundets velstand. Altså: Hvordan får vi flere seniorer til at fortsætte $\mathrm{i}$ arbejde?

Tænketanken kunne også havde anlagt et kvalitativt arbejdslivsperspektiv på seniorer: Hvordan skaber vi som samfund et godt og udfordrende arbejdsliv for seniorer? Det ville have givet et andet resultat af Seniortænketankens arbejde.

Niels Møller, lektor, sociolog

Institut for Materialer og Produktion, Aalborg Universitet

e-mail: nielsmoeller999@gmail.com

Lisbet Theilgaard, cand.mag. og tidligere ledelseskonsulent.

e-mail: lisbettheilgaard@gmail.com

Mads Christoffersen, kultursociolog og forfatter.

e-mail:mchr@mondogrande.dk 